\title{
The Holistic Rehabilitation Model for Drug Addicts, Phubbing and Conduct Disorder in Boarding Schools
}

\author{
Adhi Iman Sulaiman ${ }^{1}$, Agoeng Noegroho ${ }^{2}$, Suryanto $^{3} \&$ Sri Weningsih $^{4}$ \\ ${ }^{1}$ Department of Communication Science, Jenderal Soedirman University, Indonesia \\ ${ }^{2}$ Master Program of Communication Science, Jenderal Soedirman University, Indonesia \\ ${ }^{3}$ Departement of Public Health, Jenderal Soedirman University, Indonesia \\ ${ }^{4}$ Indonesia Open University in Purwokerto, Central Java, Indonesia \\ Correspondence: Dr. Adhi Iman Sulaiman, Departement of Communication Science, J1. HR Boenyamin No.993, \\ Purwokerto Sub-District, Central Java Province. E-mail: adhi.2005unsoed@gmail.com
}

Received: October 22, 2019; Accepted: November 18, 2019; Published: November 23, 2019

The research is financed by Institute for Research and Community Service in Jenderal Soedirman University.

\begin{abstract}
Human resources are important for the process of achieving development goals in addition to natural and economic resources, but by the cases of drug abuse and addiction as well as phubbing and conduct disorder among children and adolescents make serious problems and threats to the progress of national development. The boarding school has the function as an educational and social institution that actively carries out prevention and rehabilitation of drug abuse and conduct disorders. The research aims to creat the holistic rehabilitation models for drug addicts, phubbing, and conduct disorder in boarding school. The study used qualitative research method of phenomenology by determining informants purposively including foundation management, clients or rehabilitation patients, and counselors or assistants. The research location took place at the Nurul Firdaus Islamic Boarding School as rehabilitation center in Kertaraharja Village, Panumbangan District, Ciamis Regency, West Java Province of Indonesia. Data were collected by direct observation, dialogue and documentation. Data analysis is carried out through interactive models with stages of data collection, reducing, verification, triangulation, categorization and making conclusions. The results of the study showed that Nurul Firdaus Islamic Boarding School (1) Categorize and accept clients affected by drug abuse and addiction, phubbing, also conduct disorder. (2) Perform persuasive and therapeutic communication in holistic rehabilitation methods including medical, non-medical such as spiritual, herbal, cupping, and acupuncture, as well as therapeutic methods with psychotherapy and hypnotherapy. (3) Post rehabilitation as an important part in preventing further reusing of drugs, phubbing and conduct disorder by providing positive and productive media of interaction such as activities in the fields of education, entrepreneurship, sports, and becoming social activist organizations.
\end{abstract}

Keywords: drug addicts, education, boarding school, holistic rehabilitation, spiritual

\section{Introduction}

Human resource development becomes a determining factor in the process and achieving development goals in addition to natural, social and economic resources. Susanto (2009), Widodo et al. (2012) and Notoatmodjo (2015) stated that a nation's important and primary capital are human resources and natural resources, but human resources are more important in determining to utilize other resources and improve the welfare of the community.

However, there are obstacles and threats in development, one of which is drug abuse among adolescents and is included in the category of extraordinary crime that threatens the world and can be used as a weapon in the proxy war to paralyze the nation's power, because the average number in Indonesia is 40-50 people die per day (RRI 2018 ) or 15,000 people per year in 2018 . According to the 2017 of National Narcotics Agency executive summary survey of drug abuse Indonesia had an estimated number of narcotic abusers of 3.8 million to 4.1 million people or around $2.10 \%$ to $2.25 \%$ of the total population and 3,376,115 people in the $10-59$ year age group in 2017 and in 2018 the age range was between 15-35 years, and specifically among students in a sample of 13 provincial capitals in Indonesia, 2.29 million people (source: bnn.go.id). 
Drug abuse has major implications for the health and social and economic losses of the country. All the informants had willing to quit by rehabilitation, but it was still difficult and they reused drugs. That was because they were still influenced by the environment in which they lived. According to Hawari (2006), Martono and Joewana (2008) and Noegroho et al. (2018) an individual who has a narcotics dependency will experience a mental disorder and no longer be able to control himself naturally in his life that is the destruction of the social function to interact with society normally, loss of work, school, and unable to control himself or being frustrated.

People are prone to drug abuse and become worse at narcotics abuse. Narcotics abuse has attacked the generation of children and young people (Nur'artavia, 2017) who are the successors of development, thus this becomes a threat in the weakening of the nation. According to study results done by Salatun and Mina (2019) it is found that teenagers are vulnerable for drug abuse. Sinring and Aryani (2013) argues that the reasons are: (1) they are unstable, and quickly affected; (2) they have urge to try things; (3) they want to be accepted among their friends, (4) they get frustrated easily; (5) they want to escape from the problem.

Therefore the context of the study in this article is the importance of prevention as early as possible not only by strict law enforcement, but also by providing counseling and community empowerment from the government and civil society to provide motivation, understanding mindset and mental attitude for the general public, and addicts or ex addicts so as to prevent the danger of drug abuse. According to Kurniawansyah (2014) it is impossible to carry out development individually especially in remote area, instead there must be colaboration between the government that must accommodate the aspirations and the community.

The government has issued a serious policy in preventing narcotics abuse, namely Presidential Instruction No. 12 of 2011 concerning the Implementation of National Policies and Strategies for the Prevention and Eradication of Drug Abuse and Circulation in 2011-2015 to achieve "Indonesia a Drug-Free Country" by issuing program on the prevention and eradication of drug abuse which stands for national policy and strategy Prevention and Eradication of Narcotics Abuse and Circulation. This is a form of seriousness and joint commitment of all elements of society, nation and state that focus on drug prevention so that students have mindset, mental attitude, and are able to reject and prevent the circulation of drugs. Furthermore this implements empowerment to create an educational and campus environment that free from drug abuse and circulation.

The research focuses on solving the problem of the drug abuse that is not only resolved by law enforcement but also by preventive efforts as early as possible both before and after the incident. On one side, former drug addicts as victims must be helped or rescued, they should not be exiled, given a negative stigma and become a marginalized community. If this continues, the former drug addicts will be increasingly distant, trapped and frustrated and become enemies of the community.

The prevention for former drug addicts is not only through treatment with psychology and health rehabilitation, but also through social and economic rehabilitation in the form of implementing empowerment and mentoring programs that can restore the spirit of life, mental attitude, willing or life expectancy, creativity and productivity to continue a new, better life. Based on this the author is interested in analyzing medical, non-medical (spiritual and herbal) holistic rehabilitation, psychology and hypnotherapy for drug abuse and addiction, social media and juvenile delinquency in the Boarding School of Nurul Firdaus Panumbangan, Ciamis Regency, West Java Province.

The author has conducted a preliminary and advanced study on the prevention of drug abuse and addiction based on the results of the study and research of the author from 2016 to 2018. There are boarding school namely the Nurul Ichsan Al Islami Foundation led by KH Achmad Ichsan in Kalimanah and An Nur Foundation led by KH Supono Mustajab in Bobotsari, Purbalingga Regency, Central Java, that play a role in the prevention, control and rehabilitation of drug abuse and mental disorders caused by technology negative influence. Nurul Ichsan Al Islami and An Nur rehabilitate drug addicts and mental disorders by means of (1) Medical where the drug addicts are examined by a special doctor and treated overnight or can also be treated routinely in a hospital that has been appointed by the National Narcotics Agency and the Ministry of Social Affairs. (2) Rehabilitation of drug abuse is conducted in institutions, foundations and boarding schools that have been officially appointed and become partners National Narcotics Agency and the Ministry of Social Affairs, both in-patient and outpatient and nonmedical patient are given herbal and spiritual handling. (3) Social and economic rehabilitation for former drug addicts who have been declared no longer addicted to narcotics, they are given theraphy of social and economic activities so that they have enthusiasm, knowledge and skills and can be accepted or resocialized with family, groups and communities.

Thus the main arguments can be made based on background, context and focus as well as preliminary studies that show rehabilitation with psychology, psychotherapy, medical and non-medical herbal and spiritual is a holistic 
rehabilitation that is important and comprehensive which needs to be examined specifically in the boarding school of Nurul Firdaus Panoongan, Kertaraharja Village, Panumbangan District, Ciamis Regency, West Java Province.

\section{Method}

Research methods that are appropriate for the situation and condition of the subject as well as the research location at the Islamic Boarding School Foundation for drug rehabilitation, are the constructivist paradigm and phenomenological methods so as to construct the meaning of reality experienced by research subjects in a dialogical and in-depth manner (Kuswarno, 2009); (Ghony \& Almanshur, 2012).

The location of the study was determined based on preliminary study results, that was the rehabilitation of narcotics in Nurul Firdaus boarding school at Kertaraharja Village, Panumbangan District, Ciamis Regency, West Java Province of Indonesia as an alternative place for non-medical and spiritual rehabilitation of Narcotics addicts.

Research subjects are determined by purposive sampling included the chairman and administrators of the foundation or boarding school, drug addict clients who were in the process of rehabilitation, former addicts and assistants such as addiction counselors and volunteer counselors. Data collection is taken through persuasive and informal (dialogical) approaches and communication, documentation, and direct observation. Research analysis is done through interactional analysis (Miles \& Hubermen, 2013) by collecting data, reducing, verification, triangulation, categorization and drawing conclusions.

\section{Results}

The danger of drug abuse is a serious obstacle and threat to the development process, especially the development of Human Resources that will damage the mental psychology, common sense and behavior or character, especially generation of the nation and create increasingly massive marginal groups namely drug addicts and ex-addicts. Therefore the responsibility of overcoming the problem of narcotics abuse is not only the responsibility of the government in this case the National Narcotics Agency in the region and the Police, but also the universities.

The active role of universities is needed as an educational institution that prevent and control the narcotics through studies, research and community service as well as partnerships with National Narcotics Agency and social education institutions such as Islamic boarding schools. The result is that boarding school is not only an educational institution but also a social institution that has an important role in helping to overcome community problems in this case the problem of drug abuse and addiction, phubbing and psychiatric disorders.

Nurul Firdaus Islamic Boarding School (Ponpes) is located in Panoongan, Kertaraharja Village, Panumbangan District, Ciamis Regency, West Java Province. Nurul Firdaus Islamic Boarding School is a type of Boarding Based School that was inspired by Shaykh Abdullah bin Nur Muhammad, founder of Suryalaya Islamic Boarding School. Nurul Firdaus was led by Dr. Gumilar in 2000 and was only able to open a formal education institution in 2009 by recruiting religious teachers from Suryalaya Islamic Boarding School.

Nurul Firdaus Islamic Boarding School not only provides a place for narcotics rehabilitation and addiction to social media and mental disorders but also has complete educational institutions (school) from Early Childhood Religious Education, Elementary School, Junior High School, and Teaching Training Schools and Islamic Boarding Schools Nurul Firdaus Islamic Boarding School handles drug addiction rehabilitation and psychiatric disorders as in previous research (2016-2018) Nurul Ichsan Al Islami Kalimanah and An Nur Bobotsari Purbalingga District (Noegroho et al., 2018).

Nurul Firdaus accepts clients who are so addicted to social media such as online games and chatting that they forget time, duties or rights and obligations. They rarely interact directly and barely do activities in the real world. Symptoms of social media addiction according to Nurul Firdaus is a dangerous disorder similar to drug addiction called Phubbing. Phubbing is a term refering to individuals who do not want to interact and mingle with families, groups, and communities with daily activities in the real world due to addiction in cyberspace or virtual with social media through the internet network on cellphones and computers or laptops. Excessive dependence on social media or phubbing can cause other psychiatric illnesses such as cyberchondria, social addiction, nomophobia, pornography, and phobosocial.

According to Ahmadi and Sulaiman (2009) the power of the mass media with its setting agenda can influence the thinking, attitudes and behavior of the public. Hanika (2015), Youarti and Hidayah (2018), Normawati et al. (2018) and Guazzini, et al. (2019) state phubbing is an abbreviation of phone and snubbing as an attitude of hurting opponents of interaction by using smartphones excessively because he or she is addicted to cellphone and ignores direct social interaction. Phubbing can damage interactions with others, this is the impact of new media with information technology and communication that affect people's culture. Al-Saggaf and O'Donnel (2019) stated 
that phubbing is a negative impact of the addiction to use mobile phones that violates the basic needs of humans to interact socially. Therefore it affects social change in the era of modern technology.

Nurul Firdaus also categorized the misbehavior of children who were out of control as a form of threat of psychiatric danger and social interaction that had to be rehabilitated. So that Nurul Firdaus Islamic Boarding School deals with clients who have deviant behavior disorder from children aged 6-8 years called Conduct Disorder. It is a distorted behavior that violates ethics and norms both in the family and school environment, the examples are lying, stealing, committing acts of violence, and destructive behaviour.

Conduct Disorder is generally carried out by children to their own friends than to their families, the cause is an unstable mentality, lack of attention and affection, wrong relations, venting out of revenge or disappointment. Furthermore Conduct Disorder can also be caused by thoughts and mental attitudes influenced by free viewing on social media, especially in movies, YouTube and games or online games. The formation of a free character without rules of value, the lack of communication or direct interaction with family and others, the almost unlimited freedom to freely release emotions in cyberspace (the internet) will make children rebel and disobey the rules in interacting in the real world where there are real norms, ethics, rights and obligations.

As according to Kearney (2003) Conduct Disorder is the behavior of children or adolescents that is repetitive but not in accordance with the values of truth, norms, and ethics that exist in society. Novitasari and Kumala (2009) stated that behavioral disorders in children and adolescents who are anti-social caused difficulties in interacting and following existing rules.

They do not want to go to school and often experience conflict. Rini (2010) explains conduct disorder violates ethics, norms and even laws. The examples are uncontrolled emotions by hitting and damaging (vandalism), fighting, and taunting. Further Wenar and Kerig (2011) stated Conduct Disorder indicates the attitude and aggressive behavior towards humans and animals, damaging, lying, stealing and violating the rules.

\section{Discussion}

\subsection{The Role of Nurul Firdaus Boarding School in Holistic Rehabilitation}

Based on research results, The Nurul Firdaus categorizes drug abuse and addiction and phubbing, as well as deviant behavior of children and adolescents (Conduct Disorder) as symptoms of social and psychological illnesses that must be anticipated, dealt with and seriously rehabilitated. This is caused by curiousity, negative influence of the invitation of friends and social groups, lack of self restraint, lack of social control both in the family, community environment and other environmental activities such as at school or work, have personal problems, stress and frustration, running from reality, the negative impact of influence and freedom of social media. Based on the identification and analysis results, Nurul Firdaus handles rehabilitation as shown in Figure 1.

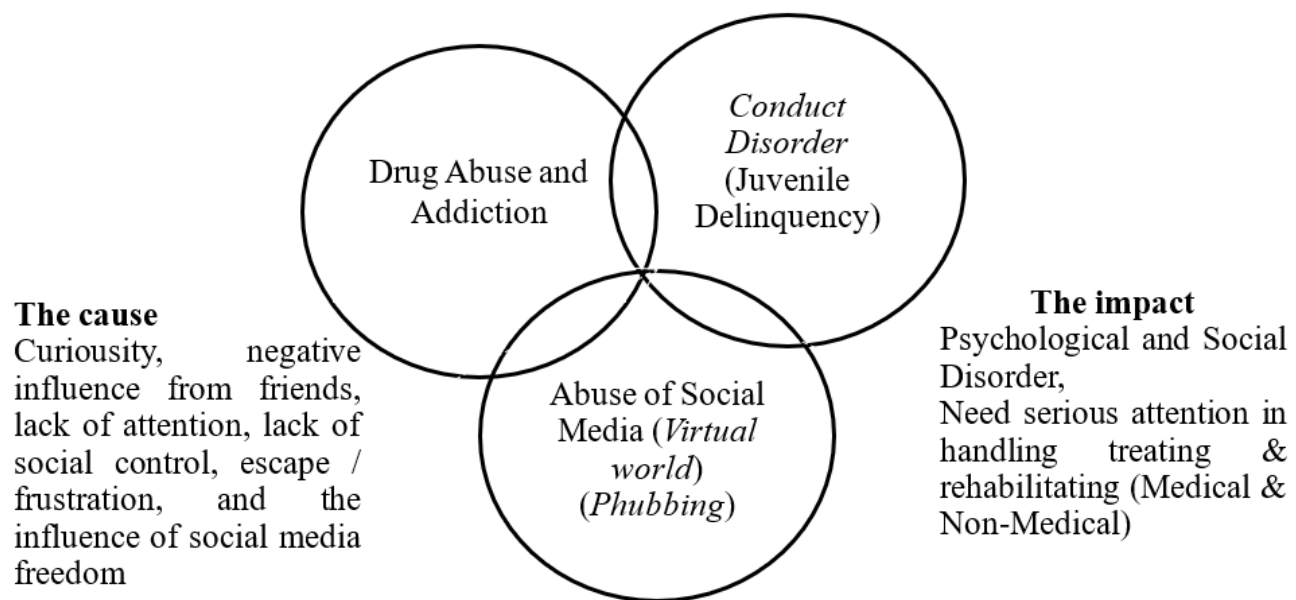

Figure 1. Categories of Handling Rehabilitation in Nurul Firdaus Boarding School

Prevention of drug abuse is not only resolved by law enforcement, but also by early prevention, because it will damage the generation and the future of the nation. Prevention of Drug Addicts, Phubbing and Conduct Disorder is not only done by the therapy of mental and health or medical and psychological rehabilitation factors, but also by social and economic rehabilitation such as empowerment and assistance programs that can restore motivation, productivity and life expectancy. Former drug addicts, including marginalized groups are isolated because of 
negative stigma, thus as victims they must be helped. If they aren't given positive activities, former drug addicts will be trapped and frustrated and potentially cause social resistance in the community.

The rehabilitation process at Nurul Firdaus Ciamis for the initial stage is the same as the Foundation that has been previously studied from Noegroho et al. (2018) namely in the Islamic Boarding School Nurul Ichsan Al Islami in Kalimanah Purbalingga which only rehabilitates non-medical with spiritual and herbal. While An-Nur Clinic in Bobotsari Purbalingga in Central Java Province mixes medical and non-medical treatment with spiritual and herbs. The similarities are the testing or checking process, each prospective patient or client of a drug addict who is going to be rehabilitated is examined first in a designated hospital as a reference for handling or rehabilitating Narcotics or Regional Hospitals in the district. However, if Nurul Ichsan Islamic Boarding School Kalimanah Purbalingga is not too strict about this, the prospective patients will be immediately accepted and processed in the second stage : approach and dialogue.

After a client had done a medical check-up, he got a doctor's certificate from the regional hospital that was officially appointed, in order to confirm and give more detail information and define diagnosis of the client's condition using the type of Narcotics, the duration of using the Narcotics and the impact that has been experienced. Thus the patient gets an important note for the rehabilitation process.

Although according to the counselor, assistant and facilitator at the three research sites, the physical characteristics of drug addict clients can be known just by looking at the body condition, eyes and hands and body language, including from the recognition of the person closest to the client and the doctor who examined.

Nurul Firdaus Islamic Boarding School as a rehabilitation place for drug addicts is still independent, has not yet become a Report Obligatory Recipient Institution which is officially appointed or a partner of the District National Narcotics Agency and or the Ministry of Social Affairs. Nurul Firdaus has a social and independent role that not only rehabilitates drug addicts but also clients who are addicted to online games (Phubbing) and Conduct Disorder that have the same behavior changes caused by drugs.

Personal and dialogical approach are conducted by the facilitators and counselors to approach, communicate or persuade dialogue with the people closest to the client who knows the history and events of the client falling into drug abuse and phubbing and mental disorders. The process starts from identifying the client about personality or personality traits, family circumstances, friends or groups of friends, causes and motives for drug use, social media and mental disorders to the impacts that have been experienced and the healing process that has been sought. After the personal history data had been collected, the causes and motives of the client, the companion, counselor, and facilitator focused on persuasive communication and therapeutic communication to the client or patient by introducing and passing an approach so that the patients will get to know each other, accept and feel close as well as build solidarity.

According to DeVito (2016) the purpose of persuasive communication is to persuade and influence or change beliefs, thoughts, perceptions, opinions, attitudes and behaviors, by verbal and non-verbal behavior to the communicant. Important elements that determine persuasive communication are the credibility and competence of the communicator, the message and information conveyed must be easily understood and rational so that it can be easily accepted by the communicant and environment. Purnawan (2002) stated that the term persuasion came from the Latin language that was persuasion and persuader which mean to persuade, invite and seduce. Effendy (2009) describes persuasive communication in the form of messages that motivate, build good relations and opinions with individuals and groups.

At this stage the facilitators and concelors carry out therapeutic communication that provides motivation, understanding and care in order to build close, open and confortable relation between between the client and his partner, advisor, and facilitator. Persuasive and therapeutic communication done by counselors are very helpful in the rehabilitation process of patients, creating mutual respect and trust (Kulikowski, 2013).

Therapeutic communication cannot be separated from informal persuasive communication with an emphasis on building motivation, advice and interaction accepting, trusting, being open, and comfortable in the context of building hope or optimism to recover, to resist, and be patient. Concelors provide knowledge, understanding, and real examples of the causes and effects of health problems and the healing process that fosters optimism and healing advice.

Therapeutic communication according to Mundakir (2006) and Zen (2013) includes personal communication with the starting point of mutual understanding and needs between nurses and clients with the principles of open dialogue, empathy, lots of listening and understanding slings. 
Therapeutic communication has the function of helping clients to reduce the burden of feelings and thoughts, and further foster mental and attitude to take action, eliminate doubts and fears in changing situations for healing. Next the patients can influence himself, others and the physical environment (Evans \& Lindsay, 2014). Therapeutic communication is very helpful in the rehabilitation process of a drug addict healing program to change the mindset, behavior, and lifestyle that is better, well organized and free of drug abuse.

Therapeutic communication is carried out with the principles of respect, sincerity, empathy, trust, and patient confidentiality (Prasanti, 2017). Therapeutic communication is related to spiritual communication as a strategy to train clients through verbal and nonverbal communication interactions in personal communication when guiding and consulting, as well as group communication when implementing Naqsabandiyyah Tariqat Naqsabandiyyah, namely; talqin dhikr, bathing repentance, prayer, dhikr and completing reading $\mathrm{Al}$ Qur'an, in a hope that patient can create and regrow awareness, comfort and calm (Muliawan, 2017).

The next stage of persuasive and therapeutic communication process to the person closest to the client and especially to the client himself takes time, depending on the psychological and medical characteristics of the client himself, the more severe the experienced condition the longer the process will be. Thus the main key of the rehabilitation process are determination and high motivation and client awareness to recover, including the support and attention of those closest to client that help to ensure comfort and healing at the rehabilitation site. Therefore in the second process, it is very important and unseparated to conduct persuasive communication and therapeutic communication to those closest to the client and the client himself, the role, support and care of the people closest to the client with the counselor, mentor and facilitator.

Further the counselor and facilitator team identify and analyze the medical results, dialogue, observation and evaluation of the client specifically to determine the type of rehabilitation method that is suitable for the client. Nurul Firdaus has a rehabilitation method called SHOT (Spiritual Hypnosis Therapy), a method that combines spiritual, hypnotherapy and psychological approaches in a holistic way to provide, build and increase motivation for clients who are addicted to drug abuse, social media (phubbing) and juvenile delinquency (conduct disorder).

\subsection{Holistic Rehabilitation Model in Nurul Firdaus Boarding School}

The stages of the approach taken for rehabilitation are:

(1) Medical methods by doctors in the regional hospitals that are officially designated for drug rehabilitation by giving medicines strictly and gradually according to doctor's prescription.

(2) Non-medical rehabilitation as a spiritual approach such as disciplining the obligatory prayers in congregation and sunnah prayers, dhikr, chanting and following spiritual cleansing and Ruqyah Syar'iyyah by reading and or listening to verses of the Qur'an Healing or Islamic Exorcist to stimulate the brain simultaneously.

(3) Non-medical method with cupping or called hijamah (cupping blood) which function is to prevent blood clots and remove toxin in the blood.

(4) Non-medical methods with a full-blooded chines or acupuncture to improve blood circulation so that the body tissue can work normally.

(5) Non-medical methods with herbal therapies from certain plants as alternatives and substitutes for medicines.

(6) Hypnotherapy methods to enter, control and manage the subconscious mind to build positive suggestions and correct psychological disorders.

(7) Method of psychological rehabilitation by using persuasive and cognitive approaches, improving mindset, mental attitude and behavior, to foster awareness of the rights, obligations and responsibilities, in order to form and stimulate normal behavior.

However, from various rehabilitation methods, it depends on the condition and suitability of the client to be successfully cured, for example with spiritual and medical therapy, there is also a spiritual method with Ruqyah Syar'iyyah (according to the purity of Al Qu'an) by using water, honey and olive oil as media of prayer that should be drunk, and salt to be sown. Rehabilitation with the Ruqyah Syar'iyyah method is used for patients who are usually detected as affected by magic and negative aura so that their psyche is disturbed.

This is as Tambusai et al. (2013) and Qodariyah (2015) mention that Ruqyah Syar'iyyah is a method of rehabilitation therapy and similar to the method of psychotherapy and become an integral part of holistic therapy that can reduce and cure anxious patient because of faith and belief that foster a sense of calm and optimism becomes stronger. 
The Ruqiyah method as a form of religious therapy based on religious teachings for patients can be done by a mentor or counselor as well as done independently accompanied by a counselor or companion. Ruqyah's goal as a spiritual accomplishment is to be able to deepen belief (faith), motivation, to worship regularly, and to form good behavior, the material is like tausiah morals, worship (praying and reciting), remembrance and prayer (Said \& Syafiah, 2017); (Sya'roni \& Khotimah, 2018). The goal is to change negative thought patterns, mental and behavior into positive and productive behaviour. According to Triantoro et al. (2019) rehabilitation with ruqyah syar'iyyah approach is an alternative form when medical treatment cannot cure the patient, Muslim belives that there is the presence of unseen attacks.

Rehabilitation is conducted by psychotherapy and hypnotherapy methods. In this process the recovery of the client depends on the intention, determination and sincerity of the client who wants to recover, the support and assistance of those closest to him and his family, as well as the appropriate rehabilitation approach method which is usually medical and non-spiritual rehabilitation becomes the main method and requirements. Nurul Firdaus in rehabilitation of drug abuse and addiction as well as online games (phubbing) also conducts psychotherapy and hypnotherapy through a spiritual or Islamic medical and non-medical approach.

According to Adz Dzaky (2004), Arifin (2009), and Munir (2013) psychotherapy is the treatment and cure of an illness, whether mental, spiritual, moral or physical. In Islam there is psychotherapy with the guidance of the Qur'an and Sunnah. Corey (2009), Bakri and Barmawi (2017) state that psychotherapy helps patients to develop self-awareness on the reality that must be faced, treat depression by sharing experiences and feelings with counselors in order to find meaning and struggle to achieve a better life.

Vanderplasschen et al. (2014) stated that rehabilitation of drug addicts and psychiatric disorders can be done with a therapeutic approach that can not be separated from the psychological approach. Muhtar (2014) emphasized the relationship between Islamic psychotherapy methods and the functions of doing (1) Understanding, (2) Control, (3) Prediction, (4) Development, (5) Education, (6) Prevention, (7) Treatment and healing, (8) Sterilization, and (9) Purification. These efforts help in rehabilitation by increasing monotheism, sincerity and loving the existence of oneself and the purpose of life. Rajab et al. (2016) emphasized that psychotherapy can be a method of rehabilitation for psychiatric disorders such as stress, depression, phobia and traumatic by doing identification of the cause or background of the patient, personal approach, dialogue, following spiritual activities with prayer, dhikr, listening to lectures and reciting the Al Qur'an.

Moreover Nurul Firdaus conducted rehabilitation with medical, spiritual and psychotherapy, as well as hypnotherapy approaches. According to Novrizal (2010) approach to hypnotherapy methods effectively reduce anxiety on patients. Gunawan (2012) stated that hypnosis was an art of exploration of the subconscious and building conditions of the mind produced by suggestions to change certain perceptions and behavior. Rakhmawati et al. (2014) stated that hypnotherapy was a persuasive and personal communication process to foster positive suggestions in patients in order to stimulate positive and constructive behavior that reduce and deal with posttraumatic stress. The hypnotherapy stage consists of (1) Identifying and analyzing or studying, (2) inducing findings and facts, (3) deepening and exploring (deeping) into the subconscious, (4) cognitive or thought therapists by providing positive beliefs that eliminate trauma and stress, (5) incorporation, conclusions and decisions (termination).

The stages of holistic rehabilitation both medical and non-medically such as spiritual, ruqyah, cupping, acupuncture and herbs, hypnotherapy and psychotherapy are complementary and holistical treatments conducted by Nurul Firdaus Islamic Boarding Schools in Ciamis and Nurul Ichsan Al Islami Kalimanah and An Nur Bobosan in Purbalingga. The boarding schools not only accept clients addicted to narcotics but also psychiatric disorders such as depression, stress and frustration. However, there is difference.

Nurul Firdaus has campaigned that acute social media addiction is as dangerous as drug addiction, therefore the patient needs prevention through rehabilitation. Because of addiction to social media by accessing the internet can cause people to forget about reality, forget about the time and will not carry out activities in the real life such as studying, going to school, working and interacting directly in the real world. This happens because people are to lost in cyberspace or in the virtual world, to play online games, watch youtube and movies and chat.

According to head of Nurul Firdaus boarding school, the term social media addiction is called Phubbing, which means busy with playing mobile phones and forgetting the activities and people around them. Phubber (the subject of phubbing) become asocial or do not interact and do not mingle with others in social reality.

Watkins (2009) said that the development of social media technology networks decreased direct interaction because people prefer to use social medical that is easy, practical, and flexible. However, there is negative impact, namely : anti-social, addiction, misunderstanding, pornography, crime, and ignoring the environment. Khairuni 
(2016) said that the negative impact of uncontrolled use of social media was that children were less socialized with direct activities, lazy, addicted to online games, imitating scenes of violence, and pornography. Anstadt et al. (2013) emphasized that the development of information and communication technology should be able to be used for positive activities such as the development of knowledge, seeking information and references, becoming a medium for distance education, developing social networks and public services. In addition, Flavián, et al. (2016) said that the development of information and communication technology media influences and changes individual and social interactions.

Therefore the rehabilitation method in Nurul Firdaus is holistic, both scientific through medical methods and psychotherapy and natural with a spiritual or divine approach (religious) such as Ruqyah Shari'yyah, prayer, remembrance and recitation, acupuncture, cupping, herbs as well as hypnotherapy methods. However, the herbal approach of using plants is not the main method, this is a complement and assistance to the Ruqyah Shari'yyah method to overcome the interference of magic and witchcraft. The herbal plants are recommended to be planted around the house to reject reinforcements to prevent attacks or disturbances of magic and witchcraft, the example of the plants are palm dates, bidara and moringa trees, yellow bamboo, red roses, cactus, and olive tree.

Nurul Ichsan Al Islami Kalimanah Purbalingga uses herbal methods as the main treatment. Herbs are procecced as drink. The ingredients are red coconut water (coconut for medicine) mixed with honey wasps, red ginger, turmeric, cardamom, betel leaves wulung and Ajwa dates. The ingredients are mixed into drinks such as herbal medicine which is useful for treating patients who experience sakau or drug addiction, a substitute for drugs and vitamins. The similarity of the three Islamic Boarding Schools rehabilitation is that there is a targeted standard of time, ranging from four to six months. Patients can be cured if they follow the requirements of the rehabilitation phase on a regular basis.

The boarding schools have similar process of assisting clients in post-rehabilitation phase. Nurul Firdaus can provide assistance through social media such as telephone and WhatsApp with the clients and interact with the closest people or closest family assigned to provide assistance and monitoring clients at home and their activity environment. At this stage it becomes very important to determine the client's recovery. Because if there is no assistance, especially in daily activities, both interaction with the friend environment and through social media that has no limits as long as it has devices and access, the client will easily fall back addicted to drug abuse and social media without control.

Clients who have just returned from rehabilitation are still vulnerable and addicted to potential, so they must be accompanied and provide a medium of interaction in the family and friendship environment that is open, close and harmonious. Moreover they should be provided other media activities such as economic business activities or entrepreneurship namely: trade, agriculture, plantations, fisheries, opening cafes, and restaurants, or participating in sports activities, channeling hobbies such as arts, music and holidays. The point is the client should not be alone and lost himself or choose the wrong group of interactions.

The causes of drug abuse and addiction, social media and deviant behavior, especially in the young generation (Muhtar 2014) are curiousity, recognition from their friends, wrong relationships, negative influence of friends, escaping from personal and family or environmental problems, frustration, depression, free influence and easy access to social media and lack of family attention and the weak social control.

Therefore there must be an important concern in post rehabilitation. Patients should be provided a medium of positive activity to keep busy or no longer fall to drug abuse, social media and choosing the wrong friends. In addition there should be provided space for interaction to be active and productive in educational activities in schools and boarding school, to participate in spiritual activities such as religious studies, spiritual lectures and social activities, conduct business activities, entrepreneurship and work. Even clients who have recovered can actively become counselors, mentors and facilitators in rehabilitation institutions to share experiences, motivate and help rehabilitate.

This stated in Windyaningrum's research (2014) that commitment and support of patients' families are very important and needed not only during the rehabilitation process but also after rehabilitation or recovery even former patients can become role models and addiction counselors that help other patients.

Yolanda (2014) emphasizes that therapeutic communication in rehabilitation creates openness and closeness between counselors or companions and patients that are created on an ongoing basis. Kulikowski (2013) stated that in rehabilitation there are six important elements, namely (1) informing patients, (2) organizing nursing, (3) communication models to patients, (4) care and service to patients, (5) physiotherapists, and (6) decision-making. 
Based on the identification and analysis of the rehabilitation process at Nurul Firdaus, a rehabilitation model can be made as in Figure 2.

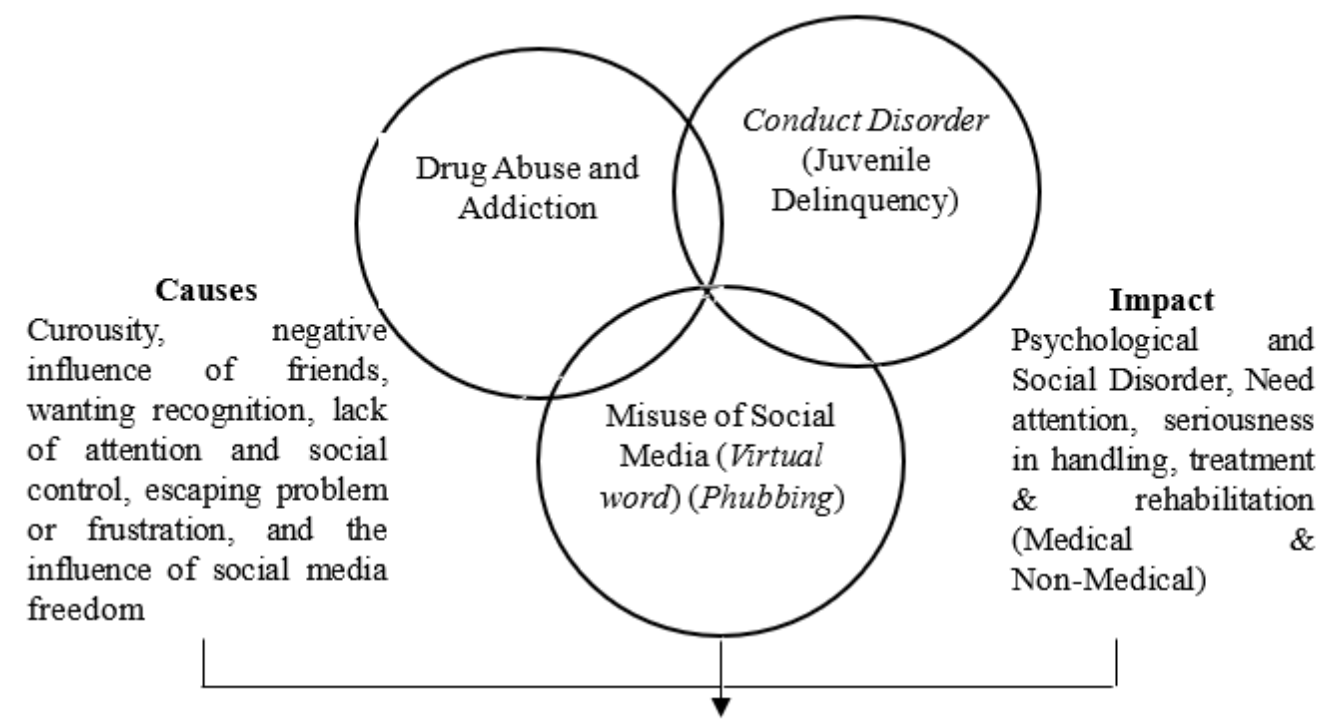

\section{Persuasive Communication, Therapeutic Communication \& Spiritual Communication In the Holistic Rehabilitation Method}

(1) Evaluation of diagnosis by doctors from hospitals that are officially appointed

(2) Dialogue with persuasive communication \& therapeutic communication with the closest person / family of the client, the client at the beginning and during the rehabilitation process (3) Rehabilitation counselors, and facilitators

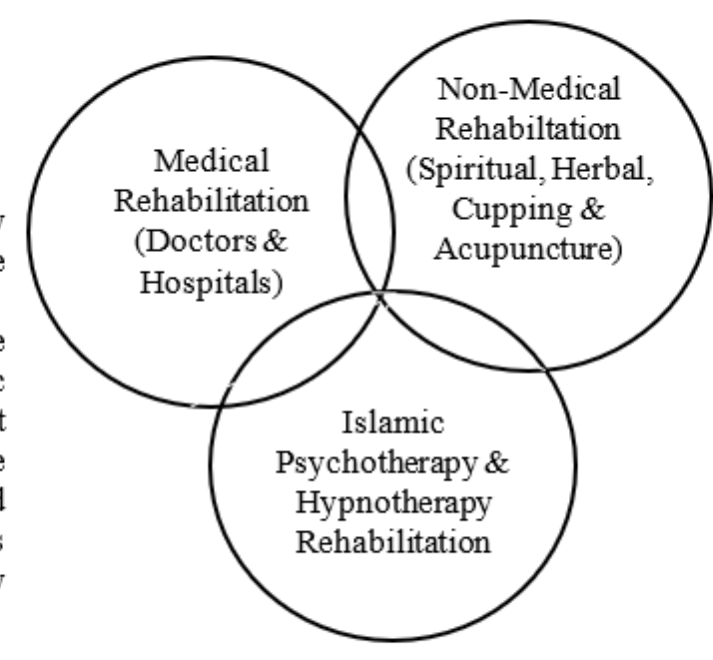

\section{Postrehabilitation I}

(1) Evaluation every month for 3-6 months of rehabilitation until going home (recovered)

(2) Monitoring clients from counselors, assistants and facilitators (outpatient at least 2 times a month 2)

(3) Monitoring or assisting clients by closest people and family

\section{Postrehabilitation II}

(1) Providing positive activity media after rehabilitation, namely sports activities, distribution of hobbies and talents, arts and entertainment

(2) Providing routine activities in educational institutions both schools andboarding school

(3) Providing business activities such as working, opening a business / being entrepreneur

(4) Following spiritual activities such as recitation, lectures and social charity activities.

(5) Become an activist and counselor in drug rehabilitation, Phubbing dan Conduct Disorder

Figure 2. Nurul Firdaus Rehabilitation Model

\section{Conclusion}

Drug abuse, social media addiction and deviant behavior, especially among children and young people can be a threat in improving the quality of human resources for development progress, thus it enters into extraordinary crimes that need serious prevention and treatment from various parties. 
Nurul Firdaus boarding school has categorized and accepted clients to be rehabilitated aside from drug abuse and addiction as well as clients of social media addiction (Phubbing), including deviant behavior of children and young people (Conduct Disorder).

Drug abuse and social media addiction (phubbing) and deviant behavior (Conduct Disorder) especially in the young generation are caused by curiousity, negative influence of friends, choosing wrong friends, wanting recognition from friends, unable to face personal and family problems, escaping from frustration, disappointment or depression, the influence of easy and free access to social media and lack of family attention and weak social control.

Nurul Firdaus boarding school has the SHOT (Spiritual Hypnosis Activity) method, which is a method that combines spiritual, hypnotherapy and psychological approaches, so that it uses holistic rehabilitation that is not only medical but also non-medical aspects such as spiritual, ruqyah, cupping, and acupuncture, and herbs.

The process of medical and non-medical rehabilitation is very effective by using persuasive communication and therapeutic communication, so that clients can be open, close, comfortable and harmonious, as well as foster motivation, desire to heal and optimism.

Post-rehabilitation stages become an important part that cannot be separated in the whole process of the rehabilitation stages so that they do not fall back into drugs and social media and deviant behavior, which are the result of the assessment after being declared healed and returning home, so there is assistance, and monitoring of clients by counselors, mentors, especially people closest to clients and family.

The post-rehabilitation stage will further provide media for active and productive activities such as opening an economic or entrepreneurial business, sports activities, channeling hobbies, entertainment and other spiritual activities such as recitation, schooling or boarding school, actively participating in social organization activities, becoming activists, counselors, and companion in the rehabilitation of drug addicts, Phubbing and Conduct Disorder.

\section{Acknowledgments}

Thank you to Institute for Research and Community Service in Jenderal Soedirman University for providing opportunities and supporting research, then to the management and counselors at Nurul Firdaus Islamic Boarding School in Ciamis West Java for their cooperation so that the research can be carried out well.

\section{References}

Adz Dzaky, M. H. B. (2004). Konseling dan Psikoterapi Islam. Yogyakarta : Fajar Pustaka Baru.

Al-Saggaf, Y., \& dan O'Donnel, S. B. (2019).Phubbing: Perceptions, reasons behind, predictors, and impacts. Human Behavior and Emerging Technologies, 1(2), 132-140. https://doi.org/10.1002/hbe2.137

Anstadt, S. P., Burnette, A., \& Bradley, S. (2013). Virtual Worlds: Relationship Between Real Life and Experience in Second Life. International Review of Research in Open and Distance Learning, 14(4), 160-190. http://doi.org/10.19173/irrodl.v14i4.1454

Arifin, I. Z. (2009). Bimbingan Penyuluhan Islam. Jakarta: Raja Grafindo Persada.

Bakri, N., \& Barmawi (2017). Efektifitas Rehabilitasi Pecandu Narkotika Melalui Terapi Islami di Badan Narkotika Nasional (BNN) Banda Aceh. Jurnal Psikoislamedia, 2(1), 86-95. https://doi.org/10.22373/psikoislamedia.v2i1.1827

BNN, Badan Narkotika Nasional. (2019). Penggunaan Narkotika di Kalangan Remaja Meningkat. Retrieved from https://bnn.go.id/penggunaan-narkotika-kalangan-remaja-meningkat/

Corey, G. (2009). Teori, Praktek Konseling \& Psikoterapi. Bandung: Replika Aditama.

Dadi, A., \& Sulaiman, A. I. (2009). Sikap Masyarakat terhadap Pemberitaan Bahaya Flu Babi di Media Massa. Mimbar, 25(2), 181-195. https://doi.org/10.29313/mimbar.v25i2.286

DeVito, J. (2016). The Interpersonal Communication Book. New York: Pearson Education.

Effendy, O. U. (2009). Ilmu Komunikasi Teori dan Praktek. Bandung: Remaja Rosdakarya.

Evans, J. R., \& Lindsay, W. M. (2014). An introduction to Six Sigma and Process Improvement. Boston: Cengage Learning.

Flavián, C., Sanchez, S. I., \& Orus, C. (2016). The impact of virtual, augmented and mixed reality technologies on the customer experience. Journal of Business Research, 100, 547-560. https://doi.org/10.1016/j.jbusres.2018.10.050 
Ghony, M. D., \& Almanshur, F. (2012). Metodologi Penelitian Kualitatif. Jogjakarta: Ar-Ruzz Media.

Guazzini, A., Duradoni, M., Capelli, A., \& Meringolo, P. (2019). An Explorative Model to Assess Individuals' Phubbing Risk. Future Internet, 11(21), 1-13. http://doi.org/10.3390/fi11010021

Gunawan., A. W. (2012). Hypnosis: The Art of Subconscious Communication. Jakarta: Gramedia Pustaka Utama

Hanika, I. M. (2015). Fenomena Phubbing di Era Milenia: Ketergantungan Seseorang pada Smartphone terhadap Lingkungannya. Journal Interaksi, 4(1), 43-51. http://dio.org/10.14710/interaksi.4.1.42-51

Hawari, D. (2006). Penyalahgunaan dan Ketergantungan NAZA (Narkotika, Alkohol, dan Zat adiktif. Jakarta: Gaya Baru.

Instruksi Presiden RI Nomor 12 tahun 2011 tentang Pelaksanaan Kebijakan dan Strategi Nasional Pencegahan dan Pemberantasan Penyalahgunaan dan Peredaran Gelap Narkoba Tahun 2011-2015.

Kearney, C. A. (2003). Casebook In Child Behavior Disorder. Second edition. Las Vegas : University of Nevada.

Khairuni, N. (2016). Dampak Positif dan Negatif Sosial Media terhadap Pendidikan Anak. Jurnal Edukasi, 2(1), 91-106. http://dx.doi.org/10.22373/je.v2i1.693

Kulikowski, K. (2013). The importance of interpersonal communication in the process of rehabilitation. Review article. Medical Rehabilitation, 17(1), 15-20.

Kurniawansyah, H. (2014). Peran Perencanaan Dalam Pembangunan Jalan Pada Dinas Bina Marga dan Pengairan Kota Samarinda. eJournal Ilmu Pemerintahan, 2(3), 2605-2615.

Kuswarno, E. (2009). Fenomenologi: Metode Penelitian Komunikasi: Konsepsi, Pedoman, dan Contoh Penelitiannya. Bandung: Widya Padjadjaran.

Martono, L. H., \& Joewana, S. (2008). Belajar Hidup bertanggung Jawab, Menangkal Narkoba dan Kekerasan. Jakarta: Balai Pustaka

Miles, M. B., \& Huberman, A. M. (2013). Qualitative Data Analysis : A Methods Sourcebook. Thousand Oaks, United States: SAGE Publications Inc.

Muhtar. (2014). Pendekatan Spiritual dalam Rehabilitasi Sosial Korban Penyalahgunaan Narkoba di Pesantren Inabah Surabaya. Sosio Informa, 19(3), 250-259. https://doi.org/10.33007/inf.v19i3.103

Muliawan, D. (2017). Komunikasi Terapeutik Korban Penyalahgunaan Narkoba melalui Tarekat. Ilmu Dakwah. Academic Journal for Homiletic Studies, 11(1), 173-196. http://doi.org/10.15575/idajhs.v11i1.1356

Mundakir. (2006). Komunikasi Keperawatan Aplikasi Dalam Pelayanan. Yogyakarta: Graha Ilmu.

Munir, S., (2013). Bimbingan dan Konseling Islam. Jakarta: Amzah.

Noegroho, A., Sulaiman, A. I., \& Suryanto (2018). Religious Counseling as an Informal Education Approach in Rehabilitation of Drug Addicts. Journal International Educational Research, 1(2), 57-68. https://doi.org/10.30560/ier.v1n2p57

Normawati., Maryam, S., \& Priliantini, A. (2018). Pengaruh Kampanye "Let's Disconnect to Connect" terhadap Sikap Anti Phubbing; Survei pada Followers Official Account Line Starbucks Indonesia. Journal Komunikasi, Media dan Informatika, 7(3), 155-164. https://doi.org/10.31504/komunika.v7i3.1665

Notoatmodjo, S. (2015). Pengembangan Sumber Daya Manusia, Jakarta: PT. Rineka Cipta.

Novitasari, R., \& Kumala, A. (2009). Perilaku Memaafkan pada Anak dengan Conduct Disorder. Psikologika: $\begin{array}{lllll}\text { Jurnal Pemikiran } \text { dan Penelitian } & \text { Psikologi, }\end{array}$ 34. https://doi.org/10.20885/psikologika.vol14.iss1.art3

Novrizal, F. (2010). Kearifan Hipnoterapi Penurunan Derajat Kecemasan dan Gatal Pasien Liken Simpleks Kronik di Poliklinik Penyakit Kulit dan Kelamin di RSDM Surakarta. Tesis. Universitas Sebelas Maret.

Nur'artavia, M. R. (2017). Karakteristik Pelajar Penyalahguna NAPZA dan Jenis NAPZA yang Digunakan di Kota Surabaya. The Indonesian Journal of Public Health, 12(1), 27-38. https://doi.org/10.20473/ijph.v12i1.2017.27-38

Prasanti, D. (2017). Komunikasi Terapeutik Tenaga Medis dalam Pemberian Informasi tentang Obat Tradisional bagi Masyarakat. MediaTor, 10(1), 53-64. https://doi.org/10.29313/mediator.v10i1.2624

Purnawan, E. A. (2002). Dynamic Persuasion: Persuasif Efektif dengan Bahasa Efektif. Jakarta: Gramedia Pustaka Utama. 
Qodariah, S. (2015). Pengaruh Terapi Ruqyah Syar'iyyah Terhadap Penurunan Tingkat Kecemasan. Scientica: Jurnal Sosial Humaniora, 2(2), 23-37. https://doi.org/10.29313/scientica.v2i2.2446

Rajab, K., Zein, M., \& Bardansyah, Y. (2016). Rekonstruksi Psikoterapi Islam: Telaah Atas Model Pemulihan Mental Pondok Pesantren dan Rehabilitasi Mental Az-Zainy, Malang, Jawa Timur . Pekanbaru: Cahaya Firdaus.

Rakhmawati, R., Putra, K. R., Perdana, F. R. B., \& Hardianto. (2014). Metode Keperawatan Komplementer Hipnoterapi untuk Menurunkan Efek Stress Pasca Trauma Tingkat Sedang 181 pada Fase Rehabilitasi Sistem Penanggulangan Kegawatdaruratan Terpadu (SPGDT). Jurnal Keperawatan, 5(2), 178-184. https://doi.org/10.22219/jk.v5i2.2347

Rini, I. R. S. (2010). Mengenali Gejala dan Penyebab dari Conduct Disorder. Psycho Idea, 8(1), 1-17. http://doi.org/10.30595/psychoidea.v8i1.194

RRI, Radio Republik Indonesia. (2017). Penyalahgunaan Narkoba termasuk Extraordinary Crime. Retrieved from http://rri.co.id/post/berita/393182/budaya/penyalahgunaan_narkoba_termasuk_extraordinary_crime. html

Said, M., \& Syafiah. (2017). Sistem Pelayanan Pemulihan Ketergantungan Napza pada RS Jiwa Tampan Provinsi Riau dalam Perspektif Hukum Islam. Jurnal Hukum Islam, 17(2), 47-71. https://doi.org/10.24014/hi.v17i2.4326

Salatun, R., \& Mina, R. (2019). Penyuluhan Narkoba Sebagai Upaya Preventif Peredaran Gelap Narkoba Di Masyarakat. Monsu'ani Tono: Jurnal Pengabdian Masyarakat, 2(1), 26-30. https://doi.org/10.32529/tano.v2i1.223

Sinring, A., \& Aryani, F. (2013). Faktor Penyebab Kecenderungan Menggunakan narkoba di Kalangan Siswa SMA. Proceeding Seminar Internasional. Fakultas Ilmu Pendidikan Universitas Negeri Medan 29-31 Oktober 2013, 3-12.

Susanto, D. (2009). Strategi Peningkatan Kapasitas Modal Sosial dan Kualitas Sumber Daya Manusia Pendamping Pengembangan Masyarakat. Bogor: Fakultas Ekologi Manusia IPB.

Sya'roni., \& Khotimah, K. (2018). Terapi Ruqyah dalam Pemulihan Kesehatan Mental. Journal of Islamic Guidance and Conseling, 2(1), 79-93. https://doi.org/10.30631/jigc.v2i1.10

Tambusai, M. B. (2013). Halal-Haram Ruqyah. Jakarta : Pustaka Al-Kautsar.

Triantoro, D. A., Husna, F., \& Amna, A. (2019). Ruqyah Syar'iyyah: Alternatif Pengobatan, Kesalehan, Islamisme dan Pasar Islam. Harmoni: Jurnal Multikultural \& Multireligius, 17(2), 460-478. https://doi.org/10.32488/harmoni.v18i1.354

Vanderplasschen, W., Vandevelde, S., \& Broekaert, E. (2014). Therapeutic Communities for Treating addictions in Europe: Evidence, current practices and future challenges. Luxembourg: Publications Office of the European Union.

Watkins, S. C. (2009). The Young and the Digital: What the Migration to Social Network Sites, Games, and Anytime, Anywhere Media Means for Our Future.'UK: Beacon Press.

Wenar, C., \& Kerig, P. (2011). Developmental Psychopathology: From Infancy Through Adolescence. New York: McGraw-Hill.

Widodo, A., Waridin, \& Kodoatie, J. M. (2012). Analisis Pengaruh Pengeluaran Pemerintah Di Sektor Pendidikan Dan Kesehatan Terhadap Pengentasan Kemiskinan Melalui Peningkatan Pembangunan Manusia Di Provinsi Jawa Tengah. Jurnal Dinamika Ekonomi Pembangunan, 1(1), 25-42. https://doi.org/10.14710/jdep.1.1.25-42

Windyaningrum, R. (2014). Komunikasi Terapeutik Konselor Adiksi pada Korban Penyalahgunaan Narkoba di Rumah Palma Therapeutik Community Kabupaten Bandung Barat. Jurnal Kajian Komunikasi, 2(2), 173-185. https://doi.org/10.24198/jkk.v2i2.7384

Yolanda, W. T. (2014). Rehabilitasi di Pusat Perawatan Pecandu Narkoba Ditinjau dari Komunikasi Terapeutik. Jurnal Ilmu Komunikasi, 5(1), 13-27.

Youarti, I. E., \& Hidayah, N. (2018). Perilaku Phubbing Sebagai Karakter Remaja Generasi Z. Jurnal Fokus Konseling, 4(1), 143-152. https://doi.org/10.26638/jfk.553.2099

Zen, P. M. H. (2013). Panduan Komunikasi Efektif Untuk Bekal Keperawatan Profesional. Yogjakarta: D-Medika. 


\section{Copyrights}

Copyright for this article is retained by the author(s), with first publication rights granted to the journal.

This is an open-access article distributed under the terms and conditions of the Creative Commons Attribution license (http://creativecommons.org/licenses/by/4.0/). 